\title{
The Empirical Study of Education in Guizhou Province - Taking L Village as an Example
}

\author{
Shuang $\mathrm{Yu}^{1, \mathrm{a}}$, Guang $\mathrm{Li}^{1, \mathrm{~b}}{ }^{*}$ and Yue Qiu ${ }^{1, \mathrm{c}}$ \\ ${ }^{1}$ College of Resource and Environment, Anshun University, Anshun 561000 \\ asling77@ sina.com, ${ }^{\mathrm{b}} \lg 20029 @ 126 . c 0 m$ \\ *the corresponding author
}

Keywords: Guizhou Province; Peasant education; Countermeasures and suggestions

Abstract. Guizhou Province is one of the most developed provinces in south China with a large proportion of poverty-stricken counties in the province. This paper takes L Village as an example to analyze the status quo and existing problems of peasant education in Guizhou Province, and puts forward corresponding countermeasures for the existing problems And advice.

Acknowledgement: This research was financially supported by the Guizhou Province Education Science Project (2016B219).

\section{贵州省农民教育的实证研究-以 $\mathrm{L}$ 村为例}

\author{
余霜，李光 ${ }^{*}$ ，邱玥 \\ 安顺学院资源与环境工程学院, 贵州 安顺 561000
}

摘要: 贵州省是我国南方岩溶极为发育的省份，全省贫困县的比例较大，本文以 $\mathrm{L}$ 村为例分析了贵州省农民教育的现状 及存在的主要问题，并针对存在的问题提出了相应的对策和建议。

关键词: 贵州省; 农民教育; 对策建议

\section{1 前言}

教育可以激发受教育者的内在潜能，使其各方面得到最充分的发展 [1]，就像斯宾塞所说得 “教育为 未来生活之准备。”中国是农业大国，农民多是客观事实，如何使我国农民的未来生活更有保障，目前研 究表明大力开展新型职业农民培育工作，着力培养一大批有文化、懂技术、擅经营、会管理的新型职业农 民是一条较好的途径。为此我国加大了农民培训的力度，自 2012 年以来，通过实施新型职业农民培育工 程，全国共培育各类新型职业农民 400 余万人。

贵州省是我国南方岩溶极为发育的省份，贫困县占全省总县域的 $66.0 \%$ [2]，而在这些地方主要的贫困 者就是农民，为此贵州省政府办公厅印发了《贵州省全民科学素质行动计划纲要实施方案》，方案明确指 出：力争使贵州省每个有培训愿望的劳动者都有机会参加一次相应的职业培训，使他们至少掌握一门实用 技能, 基本消除无技能劳动者现象, 再通过他们的示范带动周边农民共同致富, 该方案的实施极大的促进 了贫困农民的脱贫。L 村就是贵州省一个典型的贫困村，它在 2004 年以前属省级一类贫困村，后来通过全 村群众的辛勤劳动和在 “知识改变命运图书室” 的不断学习，以及各级专家开展的专项培训，到 2010 年 
该村的农民人均纯收入达 4503 元, 年增长 $25.2 \%$ 。虽然农民教育在该村已经有所开展, 但还是有许多问题 涌现出来，这些问题也反映出贵州省农民教育的普遍问题，具有一定的普遍性。

\section{2 现状及存在的主要问题}

\section{1 农民对受教育的认识不够深刻}

农民受教育情况深刻地影响着农民的收入水平 [3]，农业部 2006 年调查了我国农户收入水平与受教育 程度的相关性, 结果表明高中户比小学户人均收人多出 1.6 倍; 初中户比小学户年人均收入多出 1.4 倍; 小学户比文盲半文盲户人均多出 0.5 倍。可见, 农民受教育的水平越高, 其收人水平也往往越多。然而农 民并不重视受教育, 主要原因是他们的生存压力巨大, 没有精力用在受教育上, 导致农民参加培训教育的 比例极低, 据我国相关统计, 接受过一个月内的短期培训的农民只占 $8.95 \%$, 接受过初级技术教育培训的 只占 $2.29 \%$ ，接受过中等技术教育的仅占 $0.77 \%$ ，而没有接受过技术培训的竞高达 $82.41 \%$ 。

由于 L 村交通不便，很多农民培训没有在该村开展，2015 年只有 2 名贵州省“三区”科技特派员在该 村开展了培训工作, 培训农民 230 人次。同时, 该村农户对于接受培训也反应冷淡, 据调查有 $67 \%$ 的农民 认为不需要参加培训, 有 $22 \%$ 的农民认为是否参加培训都无所谓, 仅有 $11 \%$ 的农民认为有必要参加培训。 可见，该村农民对受教育的认识不够重视，这也是农民教育是否能够顺利开展的关键问题。

\section{2 当前农民教育内容脱离实际}

要培训出具有较高的文化素质和专业技能的农民群体，必须有一支高素质的教师队伍，才能完成培训 任务。为此, 各地根据当地情况, 聘请了素质高、专业理论强、实践经验丰富的专家、教授、专业技术骨 干、土专家组成讲师团队伍授课, 培训内容主要包括粮食种植与销售的生产管理方法、果树栽培概论、蔬 菜栽培概论、农作物病虫害防治、测土配方施肥技术，以及经营管理方法、政策法规等方面知识。

通过参加培训使相关农民的技术水平确有提高, 但是他们的文化基础太薄弱, 大部分农民只有小学文 化水平, 甚至有部分农民是文盲, 专家的教授内容一般都是自己熟悉的领域或者某种作物, 而这些内容并 一定是当地农民需要的, 导致培训内容脱离实际, 缺乏针对性。 $\mathrm{L}$ 村以水稻、蔬菜、草莓为主要种植作物, 而目前在该村开展的培训主要涉及菾麦种植技术、红薯加工技术、农家乐管理与经营等内容, 可见在该村 的培训内容严重脱离实际的需要, 这就要求以后的农民培训必须更加针对当地实际, 以免造成不必要的浪 费。

\section{3 培训时间难以保证}

由于当前农民对于参加培训的重视程度不够, 导致他们认为有时间参加培训还不如抓点实际生产。同 时, 农民和农业在中国市场经济下正在被边缘化 [4], 他们的经营大都是小块经营, 没有形成规模。所以, 尽管他们辛勤劳动, 但是还是无法摆脱贫穷, 这样他们更加不能妥善处理农业生产与培训学习之间的矛盾, 他们参加培训的时间也难以保证。L 村村委会领导表示, 该村有 $85 \%$ 的村民不能完整的参加某个培训, 培 训效果也相应的受到影响。

\section{4 资金投入不足}

充足的经费是开展培训活动的物质基础，从 2006 年起，农业部、财政部共同实施 “新型农民科技培 训工程” ，中央财政设立新型农民科技培训专项补助资金，并制定《中央财政新型农民科技培训补助资金 管理暂行办法》 $[5]$, 该办法在一定程度上保障了农民参加培训的经费问题, 但是资金缺口仍然很大。近 
年来 $\mathrm{L}$ 村在农民培训方面基本没有投入，导致在该村开展的培训项目较少，甚至有专家从其个人承担的科 研项目中拿出经费用于该村的农民培训, 据了解每次开展培训需要花费 1800 余元。另外, 农民每次参加 培训都要收入一定的误工费, 目前误工费为 20 元。

\section{3 对策建议}

\section{1 扩大宣传, 加深认识}

首先, 围绕 “农民希望掌握的” 和 “需要农民掌握的” 这两个方面, 及时宣传报道培训过程中涌现出 来的先进典型, 正确把握宣传方向, 通过與论引导形成农民关注、期望值高、效果好的良好培训局面。其 次, 既不摒弃原有的广播、标语等宣传方式, 又要充分利用电视台、短信、新媒体等媒介, 不断拓宽宣传 渠道, 认真做好舆论宣传工作。最后, 大力加强宣传队伍建设, 为培训宣传工作奠定人力基础。建立各级 农民培训信息网络, 及时召开农民培训情况分析会, 听取各地的情况汇报, 并出台考核办法, 将农民培训 宣传工作纳入组织工作考核范围，对宣传工作表现突出的给予表彰奖励。

\section{2 结合实际制定培训内容}

当前我国农民的学历水平较低，在这种情况下，需要依据农民不同的文化层次，首先对他们进行基础 科学知识提升, 以提高他们的文化水平。同时, 培训内容是否合理是培训成功与否的关键, 所以在制定培 训计划时, 组织者必须根据不同地区农业生产的特点, 因地制宜地对当地农民开展相应的农业技术培训, 只有这样才能保证培训效果和提高农民参与培训的积极性。

\section{3 利用农闲合理安排培训}

当进入了农闲时间，农民的空闲时间十分充足，如果他们积极地利用这段时间进行农技培训，可以为 以后的农业生产积累知识, 所以农闲时节是 “充电” 的最佳时节, 农民朋友应充分利用好这一时间对农事 进行总结, 认真学习实用技术和他人的致富经验, 提高自身的致富本领, 为以后的农业生产打好基础。

\section{4 千方百计筹措资金, 满足农民培训的需要}

经费是各项工作能够顺利开展的基本保障，为了更好的开展培训工作，各级政府应该千方百计筹措资 金，积极支持农民培训工作的开展，有力的推动农民培训工作的健康发展。

加快开展农民教育、提高农民科学文化水平是促进传统农业向现代农业转变有效手段, 也是从根本上 解决农村、贫困、农民问题的关键。因此，开展农民教育应该成为各级政府重点开展的惠农项目。

\section{作者简介：}

余霜 $(1982$ 一) , 女, 四川沪州人, 博士，教授。主要从事农业资源与环境经济管理研究。E-mai1： ysling77@sina.com。

*通讯作者: 李光 (1980-), 男, 河南商丘人, 博士, 教授。主要从事农业资源、作物遗传育种研究。 E-mail: 1g20029@126.com。

\section{References}

[1] P.Huang and T.P.Li: The Definition of the Educational Process and the Interpretation of Its Generating Characteristics[J], Educational Research, 2013, 34(07):18-27.(In Chinese)

[2] S.Yu: Research on Farmers' Behaviour of Participating in Rocky Desertification Control in Karst Areas - A Case Study in Guizhou Province[M], Beijing: China Agriculture Pres, 2015.(In Chinese)

[3] P.Xiao: The Influence of Rural Education on Rural Production and Residents' Income - Analysis Based on the Survey Data of Henan Province[J], Journal of Zhengzhou University (Philosophy and Social Science Edition), 2010,43(04):160-162.(In Chinese) 
[4] M.L.Tang, Y.H.Hao and S.X.Wang: The Impact of Rural Industrialization on Village Community and Farmers' Reaction[J], Journal of Business Economics, 2014,(07):42-51.(In Chinese)

[5] M.Y.Gao and Y.Z.Wang: A Brief Analysis of the Special Fund Management of New Professional Farmers[J], Farmers Science and Technology Training, 2017,(05):21-23.(In Chinese) 